\title{
Add Retention to RPD Using Endodontic Post
}

\author{
Majchrowicz M* \\ Prosthodontist/Dentist, VA Northern Indiana Health Care System, USA
}

*Corresponding author: Majchrowicz M, Prosthodontist/Dentist, VA Northern Indiana Health Care System, Fort Wayne, Indiana, USA

Received: 眥 August 01, 2019

Published: 啙August 14, 2019

\section{Short Communication}

Replacing a tooth to an existing RPD after an extraction allows the patient to have an immediate esthetic replacement. If this can be done immediately in the dental chair, then it eliminates the need for an impression(s), a lab procedure, expense and a return visit for the patient. An interim prosthesis will allow patient use of the RPD while the extraction site heals. It can also eliminate the need to make a new RPD if all esthetic and functional requirements are fulfilled. Some form of retention will be needed to secure a replacement denture tooth to the RPD. Existing clasps [1], adjacent denture teeth [2], solder or laser welded retention [3], wire loops [4] and simple undercuts have all been used to add or repair an RPD. An endodontic post can add significant retention to a resin or acrylic RPD. Use the endodontic post system drill to make a hole in the RPD base. Place a thin film of light polymerizing gel (Triad) into the drill hole before seating then securing (curing) the measured and cut post. Placing two posts provides better retention.

The new flex type RPDs are not able to be repaired using traditional repair resin. A screw type endodontic post system can be used to create retention in a flex type RPD. (Figure 1) The threads will engage the flex base material similar to dentin. Narrow and short threaded post systems work better for this application. Nontreaded endodontic posts can be placed in a Methylmethaculate resin RPD base or adjacent denture teeth with a light polymerizing gel to gain retention for addition of a denture tooth. (Figure 2) After an endodontic post(s) are secured to a RPD, a matching denture tooth can be relieved to passively fit over the post. (Figures 1 \& 2) It is important to ensure the correct orientation to esthetically and functionally replace a missing tooth. The denture tooth can then be positioned in the patient's mouth to verify correct function and esthetics. Ensure that adjacent tooth undercuts are not engaged before curing. Once correct placement is confirmed the denture tooth can be secured to the RPD over the endodontic posts with light polymerizing gel and tissue colored repair material directly (Triad gel and repair material) in the patient's mouth. Trim and polish. After the patient has healed the intaglio surface can be relined and/or a new RPD can be made.

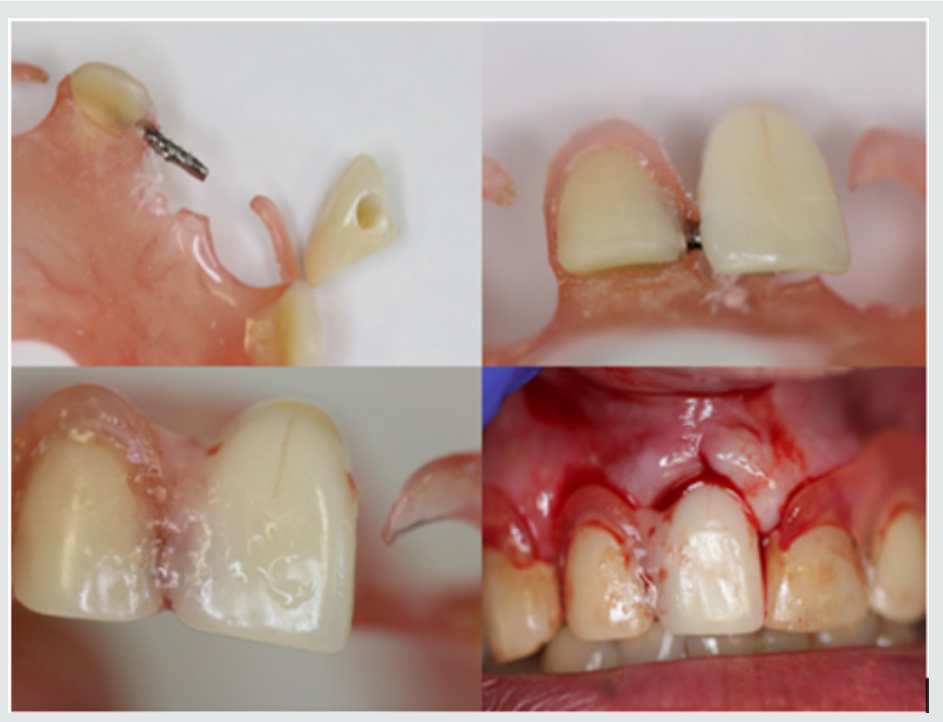

Figure 1: Treaded endodontic post in flex type RPD for retention element. 


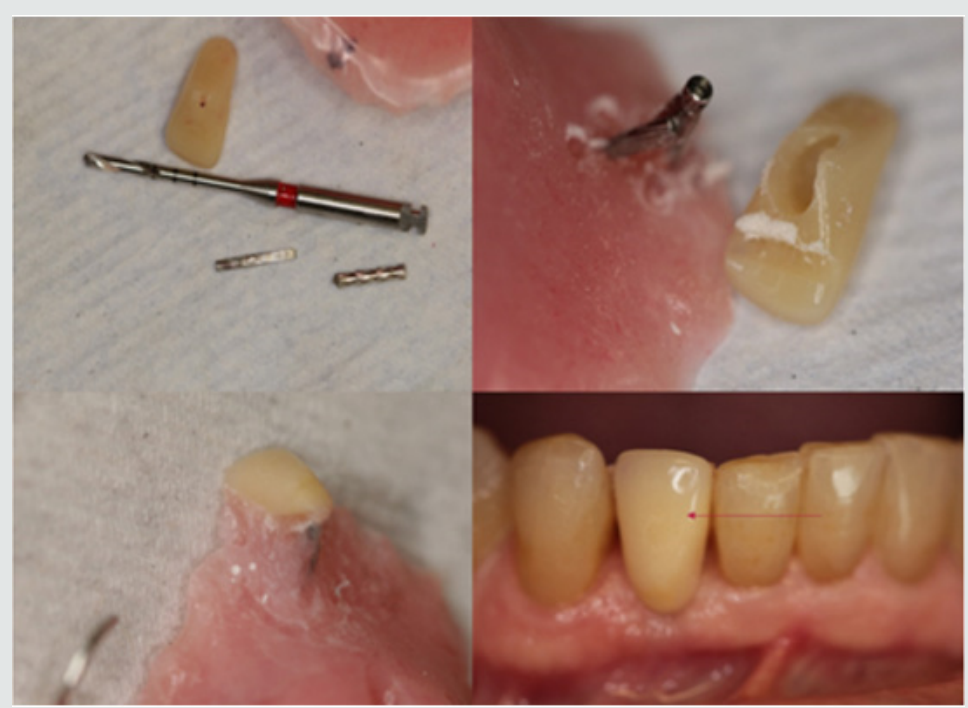

Figure 2: Non-treaded endodontic post in acrylic RPD for retentive element.

\section{References}

1. Boucher CO, Hickey JC, Zarb GA (1975) Prosthodontic Treatment for Edentulous Patients ( $7^{\text {th }}$ edn). St Louis Mosby, pp. 556-558.

2. Gehl DH (1964) Complete Denture Prosthesis (4th edn). Philadelphia. W. B. Saunders Company, pp. 416-422.
3. Sowter BJ (1968) Dental Laboratory Technology (Prosthodontic Techniques); ( $1^{\text {st }}$ edn). Chapel Hill. University of North Carolina, pp. 131-134.

4. Terry W Bradigan, Albert C Goerig, John F, Hunter (1989) Augmenting retention of a removable partial denture repair. J Prosthet Dent February 61(2): 252-253.

\section{(C) $(\oplus$ \\ This work is licensed under Creative Commons Attribution 4.0 License}

To Submit Your Article Click Here:

Submit Article

DOI: 10.32474/MADOHC.2019.03.000172

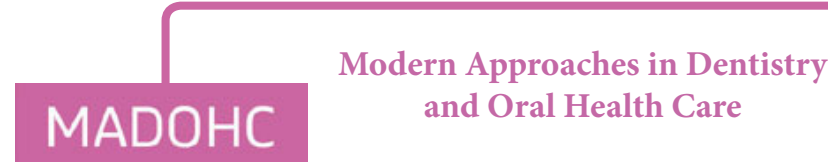

Assets of Publishing with us

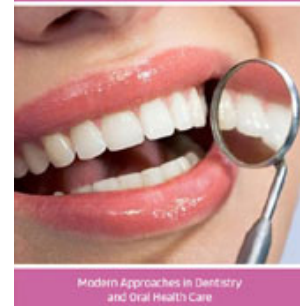

- Global archiving of articles

- Immediate, unrestricted online access

- Rigorous Peer Review Process

- Authors Retain Copyrights

- Unique DOI for all articles 